\title{
T130I mutation in HNF-4 $\alpha$ gene is a loss-of-function mutation in hepatocytes and is associated with late-onset Type 2 diabetes mellitus in Japanese subjects
}

\author{
Q. Zhu ${ }^{1}$, K. Yamagata ${ }^{1}$, A. Miura ${ }^{1}$, N. Shihara ${ }^{2}$, Y. Horikawa ${ }^{2}$, J. Takeda ${ }^{2}$, J. Miyagawa ${ }^{1}$, Y. Matsuzawa ${ }^{1}$ \\ ${ }^{1}$ Department of Internal Medicine and Molecular Science, Graduate School of Medicine, Osaka University, Osaka, Japan \\ 2 The Laboratory of Molecular Genetics, Department of Cell Biology, Institute for Molecular and Cellular Regulation, \\ Gunma University, Maebashi, Gunma, Japan
}

\section{Abstract}

Aims/hypothesis. Mutations in hepatocyte nuclear factor $(H N F)-4 \alpha$ gene cause a form of maturity-onset diabetes of the young (MODY1). The T130I mutation is a rare missense mutation, which affects a conserved amino acid in a DNA binding domain. This mutation can be found in the general population, so this variant alone does not cause MODY. However, its significance in the development of late-onset Type 2 diabetes is not known.

Methods. We screened 423 unrelated Japanese patients with late-onset Type 2 diabetes and 354 unrelated nondiabetic control subjects for the T130I mutation in the $H N F-4 \alpha$ gene. The transactivation ability of T130IHNF- $4 \alpha$ was assessed using reporter gene assay.

Results. The frequency of the T130I mutation was higher in Type 2 diabetic patients ( $p=0.015$, odds ratio $4.3,95 \%$ CI 1.24-14.98) than control subjects. The se- rum HDL-cholesterol concentration was lower in Type 2 diabetic patients with the T130I mutation compared with those without this mutation $(p=0.006)$. Reporter gene analysis showed that T130I-HNF- $4 \alpha$ transcriptional activity was not impaired compared with wild-type HNF- $4 \alpha$ in Hela and MIN6 cells, but it was reduced in HepG2 and primary cultured mouse hepatocytes $(27-78 \%$ of wild type, $p<0.05)$.

Conclusion/interpretation. Our findings suggest that T130I-HNF-4 $\alpha$ is a loss-of-function mutation in hepatocytes and that this mutation is associated with lateonset Type 2 diabetes in Japanese subjects. The T130I mutation in the $H N F-4 \alpha$ gene might be involved in the development of Type 2 diabetes in the Japanese population. [Diabetologia (2003) 46:567-573]

Keywords Maturity-onset diabetes of the young (MODY), hepatocyte nucelar factor- $4 \alpha$, type 2 diabetes, genetics, mutation.
The transcription factor hepatocyte nuclear factor (HNF)- $4 \alpha$, is a member of the steroid hormone receptor superfamily expressed in the liver, pancreatic islets, kidney and small intestine [1]. It binds to DNA as a homodimer and activates the transcription of target genes. HNF- $4 \alpha$ consists of several functional do-

Received: 30 October 2002 / Revised: 6 December 2002

Published online: 25 March 2003

(C) Springer-Verlag 2003

Corresponding author: K. Yamagata, Department of Internal Medicine and Molecular Science, Graduate School of Medicine, B5, Osaka University, 2-2 Yamada-oka, Suita, Osaka 565-0871, Japan

E-mail: kazu@imed2.med.osaka-u.ac.jp mains: an N-terminal transactivation domain (AF-1), a DNA binding domain and a functionally complex C-terminal region that forms a ligand binding domain, a dimerization interface and a transactivation domain (AF-2) [2, 3]. HNF-4 $\alpha$ plays an important role in the regulation of glucose and lipid metabolism. Late-onset Type 2 diabetes is considered to be a multifactorial disease with both genetic and environmental factors and has an uncertain mode of inheritance. In contrast, MODY is a monogenic form of Type 2 diabetes characterized by autosomal dominant inheritance, early-onset (usually before 25 years of age), and impaired insulin secretion. We have identified previously that mutations in the $H N F-4 \alpha$ gene cause a form of MODY (MODY1) [4]. Of interest, the G319S variant of the $H N F-1 \alpha / M O D Y 3$ gene was 
found to be a common cause of Type 2 diabetes in the Canadian Oji-Cree population [5]. This is an example of a different allele of the MODY gene also predisposing late-onset Type 2 diabetes. Several recent genetic studies, including a Japanese study, have obtained evidence for the linkage of an HNF- $4 \alpha$ containing region on chromosome 20q12-q13 with Type 2 diabetes $[6,7,8,9,10]$. Thus, genetic variation in the $H N F-4 \alpha$ gene might contribute to the susceptibility to Type 2 diabetes in such populations.

The T130I mutation is a missense mutation affecting a residue of the DNA binding region (A-box region). The A-box region is important for homodimerization and high-affinity DNA binding [2]. A threonine residue at position 130 is conserved in human, mouse, rat and Xenopus although the functional properties of T130I-HNF-4 $\alpha$ have yet to be determined. The T130I mutation can be found in the general population $(0-5 \%)$, so this variant alone does not cause MODY [4]. In one Danish study [11], the frequency of this allele was higher in subjects with Type 2 diabetes than in control subjects, but this finding was not confirmed in other studies of Caucasian subjects $[8,12]$. In a Japanese study, the T130I mutation was only present in Type 2 diabetic patients $(2 / 100)$ and was not found in 100 control subjects, although the difference was not statistically significant [13]. Our study was designed to further examine the diabetogenic effects of the T130I mutation by using genetic and functional analyses.

\section{Materials and methods}

Subjects. For the association study, 423 unrelated Japanese subjects with Type 2 diabetes $(253$ men and 170 women of $63.9 \pm 8.9$ years of age, BMI $23.0 \pm 3.2 \mathrm{~kg} / \mathrm{m}^{2}, \mathrm{HbA}_{1 \mathrm{c}} 7.6 \pm 1.6 \%$, means \pm SD) and 354 unrelated Japanese non-diabetic control subjects (158 men and 196 women of $63.8 \pm 18.9$ years of age, BMI $22.4 \pm 2.8 \mathrm{~kg} / \mathrm{m}^{2}, \mathrm{HbA}_{1 \mathrm{c}} 4.9 \pm 0.4 \%$ ) were enrolled. Type 2 diabetes was diagnosed in accordance with the World Health Organization criteria. All patients were diagnosed as having Type 2 diabetes after the age of 35 years. Patients with Type 1 diabetes and other types of diabetes (such as MODY) were excluded from this study. A written informed consent was obtained from each participant.

Screening for the T130I mutation in HNF-4 $\alpha$ gene. Exon 4 and flanking intron were amplified using PCR with specific primers (5'-CCACCCCCTACTCCATCCCTGT-3' and 5'-CCCTCCCGTCAGCTGCTCCA-3') [4]. The T130I mutation generates a BsmI site and it was detected by PCR-restriction fragment length polymorphism (Thr: $271 \mathrm{bp}$, Ile: $81+190 \mathrm{bp}$ ). The mutation was tested in 423 diabetic and 354 non-diabetic subjects.

Plasmids. T130I mutant HNF-4 $\alpha$ was generated from human HNF-4 $\alpha 2$ cDNA using a Chameleon Double-Stranded SiteDirected Mutagenesis kit (Stratagene, La Jolla, Calif., USA) and cloned in pcDNA3.1 expression vector (Invitrogen, San Diego, Calif., USA). The construct was verified by DNA sequencing. The reporter construct with a heterologous TK pro- moter and HNF-4 $\alpha$ binding sequences as an enhancer (pHNF4-tk-Luc), HNF-1 $\alpha$ reporter and PKL reporter constructs have been described [14].

Cell culture and luciferase assay. Mouse primary hepatocytes were prepared using collagenase perfusion method [15] and plated in six-well tissue culture plates at a density of $3 \times 10^{5}$ cells per well. HeLa, MIN6, HepG2 cells and primary hepatocytes were transfected with indicated amounts of expression and reporter vectors together with $10 \mathrm{ng}$ of pRL-TK (Promega, Madison, Wis., USA) as an internal control using Lipofectamin Plus reagent. Transactivation activities were measured after $48 \mathrm{~h}$ using the Dual Luciferase Reporter Assay system (Promega) and Lumat LB9501 Chemiluminescence (Berthold Japan, Osaka, Japan) [16].

Western blot analysis and electrophoretic mobility shift assay (EMSA). Western blot analysis was done using anti-HNF- $4 \alpha$ antibody (Santa Cruz Biotechnology, Santa Cruz, Calif., USA) as described previously [16]. Wild-type and T130IHNF- $4 \alpha$ proteins were synthesized from one $\mu \mathrm{g}$ of pcDNA3.1 expression vector using TNT T7 Quick Coupled transcriptionranslation system (Promega). In vitro translated proteins were incubated with ${ }^{32} \mathrm{P}$-labelled oligonucleotides containing HNF- $4 \alpha$ binding site of $H N F-1 \alpha$ gene (5'-GGCTGAAGTCCAAAGTTCAGTCCCTTCGC-3') in a $20 \mu \mathrm{l}$ reaction mixture [17]. In the competition binding assay, 50-fold of unlabelled probes were used as the competitor. DNA-protein complexes were analysed on $5 \%$ polyacrylamide gels using $0.5 \times$ TBE buffer. The polyclonal anti-HNF- $4 \alpha$ antiserum $(\alpha 445)$ was used for supershift analysis [1]. To determine the relative binding affinity of T130I-HNF-4 $\alpha$, increasing amounts of unlabelled competitor (10-, 25- and 50-fold) was added at non-equilibrium conditions (5-min incubation) [17].

Statistical analysis. Differences in allele frequencies were tested for statistical significance by the chi-square test and Fisher's exact test when appropriate. All clinical data are expressed as means \pm SD. Comparison of variables between groups of genotypes was done by using the two-tailed Student's $t$ test and/or the Mann-Whitney non-parametric test. Statistical analysis was done by using StatView 5.0 software (SAS institute, Cary, N.C., USA). A $p$ value less than 0.05 was considered significant.

\section{Results}

Screening for the T130I mutation in Japanese subjects. We screened 423 unrelated Japanese subjects, who had been diagnosed as having Type 2 diabetes after the age of 35 years, and 354 unrelated Japanese non-diabetic control subjects for the T130I mutation

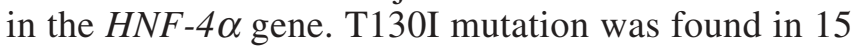
out of 423 diabetic patients $(3.5 \%)$ and in 3 out of 354 non-diabetic subjects $(0.8 \%)$, indicating that the frequency of the mutation was higher ( $p=0.015$, odds ratio $4.3,95 \%$ CI $1.24-14.98$ ) in the Type 2 diabetic group compared with the non-diabetic Japanese subjects. A previous study has showed that the frequencies of the same mutation were $2.0 \%(2 / 100)$ and $0 \%$ $(0 / 100)$ in Japanese Type 2 diabetic and control subjects, respectively [13]. Combining the results of 
Table 1. Clinical characteristics of the Type 2 diabetic subjects with and without T130I-HNF-4 $\alpha$ mutation

\begin{tabular}{|c|c|c|c|}
\hline Characteristic & Thr/Thr & Thr/Ile & $p$ \\
\hline$n$ & 408 & 15 & \\
\hline $\mathrm{M} / \mathrm{F}$ & $245 / 163$ & $8 / 7$ & \\
\hline Age at diagnosis of diabetes (years) & $47.7 \pm 8.2$ & $47.1 \pm 8.8$ & $\begin{array}{l}\mathrm{NS} \\
\text { \#28.2 } 215.2 \\
(n=40)\left(p=1.0 \times 10^{-6 * *}\right)\end{array}$ \\
\hline FPG (mg/dl) & $151 \pm 47$ & $153 \pm 44$ & NS \\
\hline $\mathrm{HbA}_{1 \mathrm{c}}(\%)$ & $7.6 \pm 1.6$ & $7.2 \pm 1.4$ & NS \\
\hline HOMA-IR (mol mU/12) & $2.4 \pm 1.8(n=134)$ & $2.2 \pm 1.1(n=8)$ & NS \\
\hline T-chol (mg/dl) & $202 \pm 36(n=244)$ & $195 \pm 39(n=9)$ & NS \\
\hline Triglyceride (mg/dl) & $139 \pm 119(n=244)$ & $158 \pm 75(n=9)$ & NS \\
\hline HDL-chol (mg/dl) & $55 \pm 18(n=239)$ & $40 \pm 13(n=9)$ & $0.006 * *$ \\
\hline
\end{tabular}

Data are means \pm SD. \# Age at diagnosis of MODY1 subjects (data are cited from references $[14,15,16,17,18,19,20,21,22]$ ). HOMA-IR=FPG $\times \mathrm{fIRI} / 22.5$. $* * p<0.01$

these two Japanese studies indicates that the T130I mutation is more strongly associated with Type 2 diabetes [diabetes; $17 / 523(3.3 \%)$, control; 3/454 (0.7\%), $p=0.0053$, odds ratio $5.05,95 \%$ CI $1.47-17.35]$. The clinical features of the diabetic patients with the Ile codon at 130 are shown (Table 1). The average age at diagnosis of diabetes with MODY1 was $28.2 \pm 15.2$ years $[18,19,20,21,22,23,24,25,26]$. The mean age at diagnosis was higher for patients with the T130I mutation $\left(47.1 \pm 8.8\right.$ years, $\left.p=1.0 \times 10^{-6}\right)$ than for those with other HNF- $4 \alpha$ mutations. There were no significant differences of the age at the onset of diabetes, BMI, maximum BMI, fasting plasma glucose concentrations, $\mathrm{HbA}_{1 \mathrm{c}}$, homeostasis model assessment of insulin resistance (HOMA-IR) [27], total cholesterol, and triglyceride concentrations between two diabetic groups with and without the T130I mutation. However, the serum HDL-cholesterol concentration was lower in the group with the T130I mutation $(p=0.006)$. The glucagon-stimulated C-peptide response was variable $(0.30,0.43,1.32$ and $1.56 \mathrm{nmol} / 1$, normal $>0.66 \mathrm{nmol} / \mathrm{l}$ ) in four diabetic patients with the T130I genotype from whom data were available. The urinary C-peptide (uCPR) concentrations in six patients tested were 4.87, 15.8, 22.2, $31.0,33.4,49.3 \mathrm{nmol} / 24 \mathrm{~h}$ (normal: 16.6 to 39.7 $\mathrm{nmol} / 24 \mathrm{~h}$ ). These findings suggest that there was variable insulin secretion among these subjects with the T130I-HNF-4 $\alpha$ mutation. This is in sharp contrast with previous reports that MODY1 mutations lead to a characteristic defect of insulin secretion [4, $19,28]$.

Functional properties of T130I-HNF-4 $\alpha$ mutant. We investigated the function of T130I-HNF-4 $\alpha$. For this purpose, HeLa cells were transfected with wild-type (WT) HNF- $4 \alpha$ or T130I-HNF-4 $\alpha$ expression vectors.
The levels of WT and T130I-HNF-4 $\alpha$ expression were similar (Fig. 1A). The transactivation ability of WT and T130I-HNF-4 $\alpha$ was assessed using the luciferase reporter gene assay. There were no significant differences of the transactivation activity between WT-HNF- $4 \alpha$ and T130I-HNF- $4 \alpha$ in HeLa cells as well as MIN6 cells, a mouse insulinoma cell line (Fig. 1B, C). However, when the same amount of expression vector was transfected into HepG2 cells, a human hepatoma cell line, the transcriptional activity of T130I-HNF-4 $\alpha$ was decreased by $46.2 \%(p<0.001)$ compared with that of WT-HNF-4 $\alpha$ (Fig. 1D). Figure $1 \mathrm{E}$ shows that impaired transactivation of T130IHNF- $4 \alpha$ in HepG 2 cells was found at all doses tested, whereas T130I-HNF- $4 \alpha$ achieved similar transactivation compared with WT-HNF- $4 \alpha$ in MIN6 cells at these doses (data not shown). HepG2 cells have heterogenous D69A mutation in the $H N F-4 \alpha$ gene [29]. To determine whether D69A mutation caused the reduced transactivation of T130I-HNF- $4 \alpha$ in HepG2 cells, we carried out a reporter gene assay using primary cultured mouse hepatocytes. Reduced transactivation of T130I-HNF-4 $\alpha$ (27.9\% of WT-HNF- $4 \alpha$, $p=9.7 \times 10^{-5}$ ) was also found in primary hepatocytes (Fig. 1F). HNF-1 $\alpha$ and L-type pyruvate kinase (PKL) are target genes for HNF-4 $\alpha$ [30]. Transcriptional activation of the $H N F-1 \alpha$ gene $(78.2 \%, p=0.024)$ and the PKL gene $(77.1 \%, p=0.002)$ by T130I-HNF-4 $\alpha$ was impaired (Fig. 1G). These data strongly suggest that T130I-HNF-4 $\alpha$ acts as a loss-of-function mutation in the hepatic cell environment. Since the A-box region is considered to be important for DNA binding [2], we also tested the DNA binding ability of T130IHNF- $4 \alpha$. When WT-HNF- $4 \alpha$ and T130I-HNF- $4 \alpha$ proteins were translated in vitro and used for EMSA, WT-HNF- $4 \alpha$ and T130I-HNF-4 $\alpha$ specifically bound to the oligonucleotide (Fig. 2A). The binding of 
A

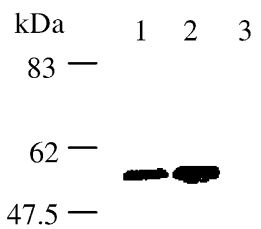

B

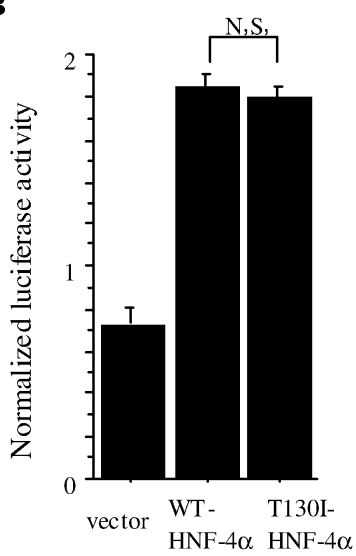

C

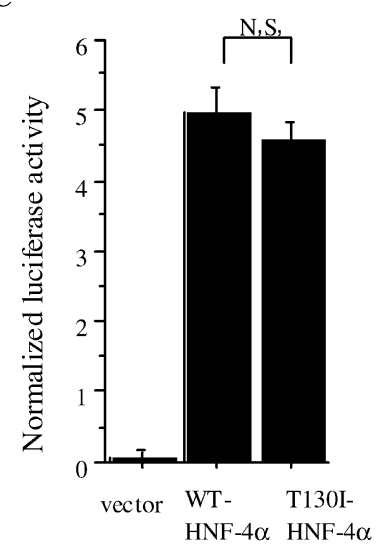

D

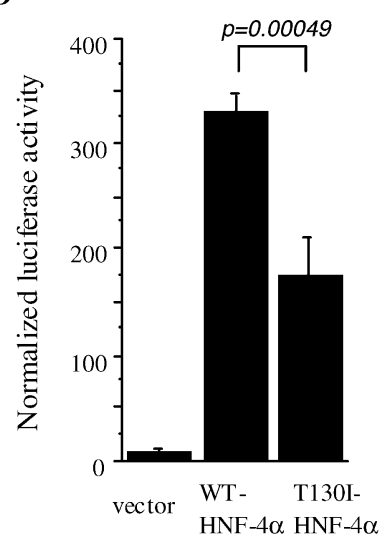

$\mathbf{E}$

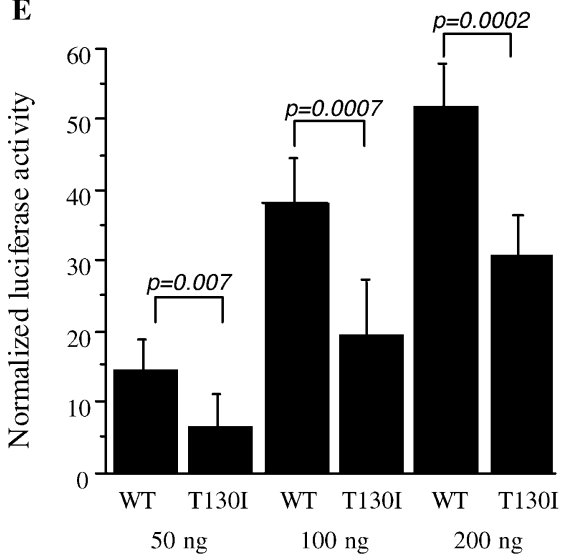

$\mathbf{F}$

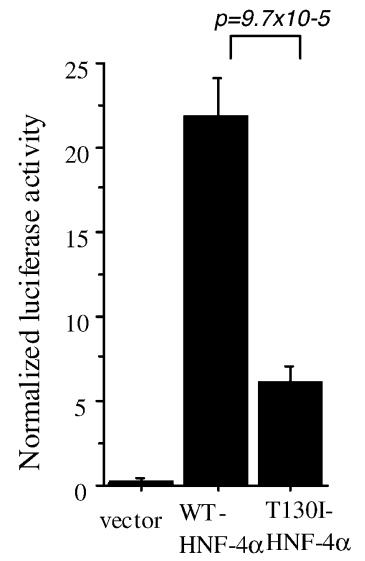

G

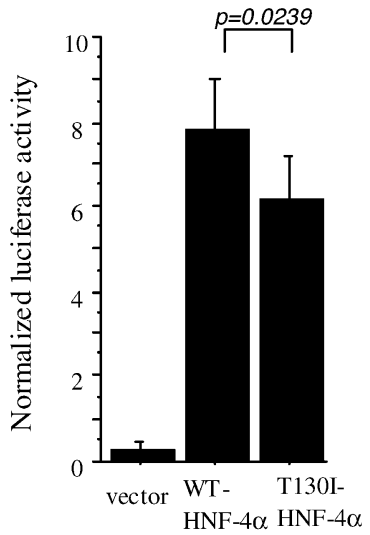

H

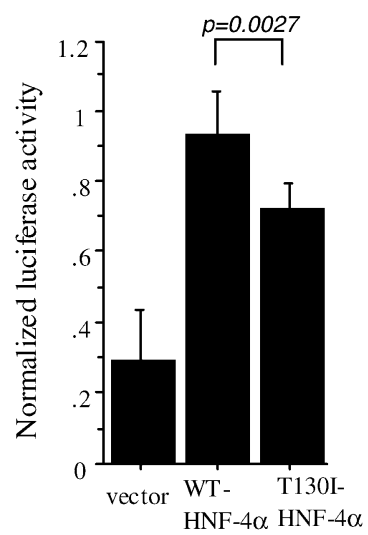

Fig. 1A-H. Transactivation activities of wild-type (WT) and T130I-HNF-4 $\alpha$. A Expression of WT and T130I-HNF-4 $\alpha$ in HeLa cells. Eight $\mu \mathrm{g}$ of expression vectors were transfected and Western blot was done after 48 h. Lane 1: WT-HNF-4 $\alpha$; Lane 2: T130I-HNF-4 $\alpha$; Lane 3: empty vector. B-D Transactivation activities of WT and T130I-HNF-4 $\alpha$ in HeLa (B), MIN6 (C) and HepG2 (D) cells. Cells were transfected with $500 \mathrm{ng}$ of expression vectors together with $100 \mathrm{ng}$ of $\mathrm{pHNF} 4-\mathrm{tk}-\mathrm{Luc}$. $\mathbf{E}$ Transactivation activities of T130I-HNF-4 $\alpha$ in HepG2 cells. Increasing amounts of expression vectors (50-200 ng) were transfected with pHNF-4tk-Luc. Data are means \pm SD values of three independent experiments. F-H Mouse primary hepatocytes were transfected with $0.5 \mu \mathrm{g}$ of expression vectors together with $100 \mathrm{ng}$ of reporter genes (F: pHNF-4-tk-Luc; G: HNF-1 $\alpha$ promoter; H PKL promoter). Data are means \pm SD values of six independent experiments
T130I-HNF-4 $\alpha$ relative to WT-HNF-4 $\alpha$ was similar under both equilibrium (Fig. 2A) and non-equilibrium conditions (Fig. 2B), suggesting that this amino acid change does not alter DNA binding in vitro. However, further studies will be necessary to examine the DNA binding ability of T130I-HNF-4 $\alpha$ in vivo (e.g., in hepatocytes).

\section{Discussion}

In this study, we showed that the T130I mutation in $H N F-4 \alpha$ gene was associated with late-onset Type 2 
A
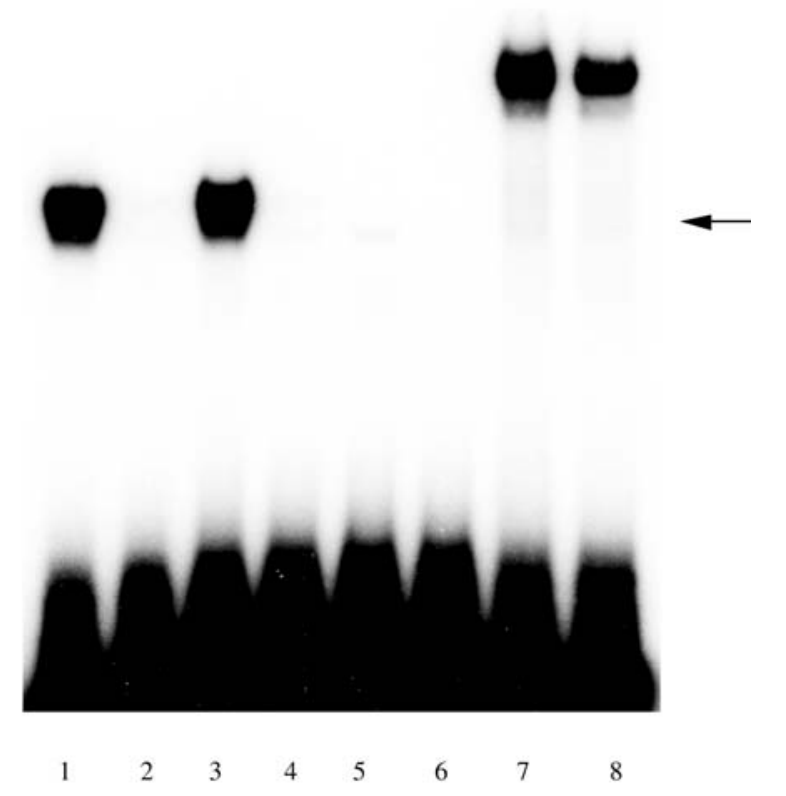

B

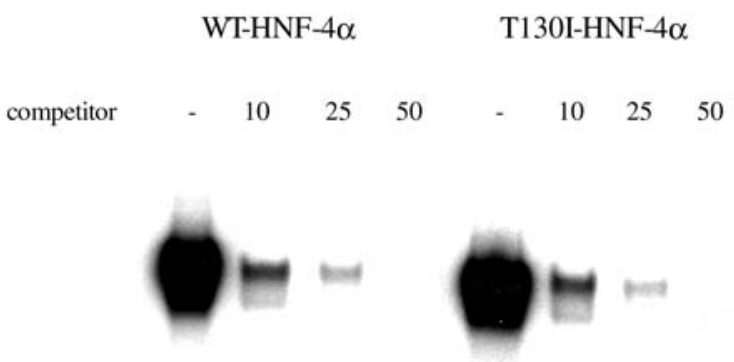

Fig. 2A, B. DNA binding ability of WT and T130I-HNF-4 $\alpha$. A HNF- $4 \alpha$ proteins were in vitro translated and used for EMSA. Equal expression levels of in vitro translated proteins were confirmed by Western blot analysis. An excess (50-fold) of unlabelled oligonucleotide was used as a competitor. Lane 1: WT-HNF-4 $\alpha$; Lane 2: WT-HNF- $4 \alpha$ and competitor; Lane 3: T130I-HNF-4 $\alpha$; Lane 4: T130I-HNF-4 $\alpha$ and competitor; Lane 5: empty vector; Lane 6: empty vector and competitor; Lane 7: WT-HNF- $4 \alpha$ and ant-HNF-4 $\alpha$ antibody; Lane 8: T130I-HNF$4 \alpha$ and anti-HNF- $4 \alpha$ antibody. Arrow shows the position of HNF-4 $\alpha /$ DNA complex. Lanes 7 and 8 show supershift of bands. B DNA binding ability of T130I-HNF- $4 \alpha$ in non-equilibrium conditions. WT-HNF- $4 \alpha$ and T130I-HNF- $4 \alpha$ were bound to the labelled oligonucleotide in the presence of increasing amounts $(10,25$ and 50 molar excess $)$ of unlabelled competitor in non-equilibrium conditions

diabetes in Japanese subjects and found that this is a loss-of-function mutation, at least in hepatocytes. It is not clear why the T130I mutation only affects transactivation activity in hepatic cells. One possible explanation is a post-translational modification that only occurs in those cells. For example, protein kinase
$\mathrm{B}$ is a downstream molecule of the insulin signalling pathway in hepatocytes. Threonine at codon 130 might be phosphorylated by protein kinase B in hepatocytes (amino acids: 125-RDRIST-130; the PKB recognition motif is $\underline{\mathrm{RX}} \underline{\mathrm{R} Y \mathrm{~S}} / \mathrm{T}$ [31]) and phosphorylation might affect the DNA binding of T130-HNF$4 \alpha$. Alternatively, hepatocytes could contain proteins that inhibit binding of the T130I mutant. Further studies will be necessary to clarify the mechanism involved. A recent genome-wide linkage study of Japanese Type 2 diabetes identified a susceptible locus around the $H N F-4 \alpha$ gene on chromosome 20q (D20S119 and D20S855) [10]. The T130I mutation of the $H N F-4 \alpha$ gene might be involved in this linkage. The molecular mechanism by which low HNF- $4 \alpha$ activity in hepatocytes, but not in pancreatic beta cells, that leads to late-onset diabetes is not known. Liver specific HNF- $4 \alpha$ knockout mice show severe fatty change of the liver [32], but no information is available on whether these mice develop Type 2 diabetes with aging. Liver is an important insulin target organ and accumulation of fat metabolites could cause insulin resistance [33]. We also found that the serum HDL-cholesterol concentration was lower in the group with the T130I mutation. Reduced triglyceride concentrations were observed in some MODY1 patients $[34,35]$. The serum concentration of HDL-cholesterol was dramatically decreased in the knockout mice [32]. Hepatic HNF- $4 \alpha$ function could be important for lipid metabolism. Clinical data on patients with the T130I genotype, as well as examination of glucose and lipid metabolism in HNF- $4 \alpha$ liver-specific knockout mice, are needed to obtain a better understanding of the role of the T130I mutation in the development of Type 2 diabetes. In addition, several rare but not MODY-causing variants have also been described in the $H N F-1 \alpha / M O D Y 3$ gene $[36,37,38]$. Some have also been found more often in Type 2 diabetic patients than controls subjects although the difference was not statistically significant for the low frequencies of the variants. Some mutations in the HNF- $4 \alpha$ and HNF- $1 \alpha$ genes could predispose to Type 2 diabetes.

Acknowledgements. We thank Dr. F.M. Sladek (University of California) for providing anti-HNF-4 $\alpha$ antibody. We also thank Dr. K. Fukui, Dr. A. Imagawa and Dr. H. Iwahashi for their valuable help with this study. This work was supported in part by a Grant-in-Aid for Scientific Research on Priority Areas (C) "Medical Genome Science" from the Ministry of Education, Culture, Sports, Science and Technology of Japan.

\section{References}

1. Sladek FM, Zhong WM, Lai E, Darnell JE Jr (1990) Liverenriched transcription factor HNF-4 is a novel member of the steroid hormone receptor superfamily. Genes Dev 4:2353-2365 
2. Jiang G, Sladek FM (1997) The DNA binding domain of hepatocyte nuclear factor 4 mediates cooperative, specific binding to DNA and heterodimerization with the retinoid $\times$ receptor alpha. J Biol Chem 272:1218-1225

3. Hadzopoulou-Cladaras M, Kistanova E, Evagelopoulou C, Zeng S, Cladaras C, Ladias JA (1997) Functional domains of the nuclear receptor hepatocyte nuclear factor 4 . J Biol Chem272:539-550

4. Yamagata K, Furuta H, Oda N et al. (1996) Mutations in the hepatocyte nuclear factor- $4 \alpha$ gene in maturity-onset diabetes of the young (MODY1). Nature 384:458-460

5. Triggs-Raine BL, Kirkpatrick RD, Kelly SL et al. (2002) HNF-1 $\alpha$ G319S, a transactivation-deficient mutant, is associated with altered dynamics of diabetes onset in an Oji-Cree community. Proc Natl Acad Sci USA 99:4614 4619

6. Zouali H, Hani EH, Philippi A et al. (1997) A susceptibility locus for early-onset non-insulin dependent (type 2) diabetes mellitus maps to chromosome 20q, proximal to the phosphoenolpyruvate carboxykinase gene. Hum Mol Genet 6:1401-1408

7. Klupa T, Malecki MT, Pezzolesi M et al. (2000) Further evidence for a susceptibility locus for type 2 diabetes on chromosome 20q13.1-q13.2. Diabetes 49:2212-2216

8. Ghosh S, Watanabe RM, Hauser ER et al. (1999) Type 2 diabetes: evidence for linkage on chromosome 20 in 716 Finnish affected sib pairs. Proc Natl Acad Sci USA 96: 2198-2203

9. Ghosh S, Watanabe RM, Valle TT et al. (2000) The Finland-United States investigation of non-insulin-dependent diabetes mellitus genetics (FUSION) study. I. An autosomal genome scan for genes that predispose to type 2 diabetes. Am J Hum Genet67:1174-1185

10. Mori Y, Otabe S, Dina C et al. (2002) Genome-wide search for type 2 diabetes in Japanese affected sib-pairs confirms susceptibility genes on $3 \mathrm{q}, 15 \mathrm{q}$, and $20 \mathrm{q}$ and identifies two new candidate Loci on $7 p$ and $11 p$. Diabetes 51:1247-1255

11. Moller AM, Urhammer SA, Dalgaard LT et al. (1997) Studies of the genetic variability of the coding region of the hepatocyte nuclear factor- $4 \alpha$ in Caucasians with maturity onset NIDDM. Diabetologia 40:980-983

12. Malecki MT, Antonellis A, Casey P et al. (1998) Exclusion of the hepatocyte nuclear factor $4 \mathrm{a}$ as a candidate gene for late-onset NIDDM linked with chromosome 20q. Diabetes 47:970-972

13. Sakurai K, Seki N, Fujii R et al. (2000) Mutations in the hepatocyte nuclear factor- $4 \alpha$ gene in Japanese with non-insulin-dependent diabetes: a nucleotide substitution in the polypyrimidine tract of intron $1 \mathrm{~b}$. Horm Metab Res 32:316-322

14. Yang Q, Yamagata K, Yamamoto K et al. (2000) R127WHNF- $4 \alpha$ is a loss of function mutation but not a rare polymorphism and causes Type II diabetes in a Japanese family with MODY1. Diabetologia 43:520-524

15. Shimomura I, Matsuda M, Hammer RE, Bashmakov Y, Brown MS, Goldstein JL (2000) Decreased IRS-2 and increased SREBP-1c lead to mixed insulin resistance and sensitivity in livers of lipodystrophic and ob/ob mice. Mol Cells 6:77-86

16. Yamagata K, Yang Q, Yamamoto K et al. (1998) Mutation $\mathrm{P} 291 \mathrm{fsinsC}$ in the transcription factor hepatocyte nuclear factor- $1 \alpha$ is dominant negative. Diabetes 47:1231-1235

17. Yang Q, Yamagata K, Yamamoto K et al. (1999) Structure/function studies of hepatocyte nuclear factor- $1 \alpha$, a diabetes-associated transcription factor. Biochem Biophys Res Commun 266:196-202
18. Furuta H, Iwasaki N, Oda N et al. (1997) Organization and partial sequence of the hepatocyte nuclear factor-4 $\alpha /$ MODY 1 gene and identification of a missense mutation, $\mathrm{R} 127 \mathrm{~W}$, in a Japanese family with MODY. Diabetes 46:1652-1657

19. Lindner T, Gragnoli C, Furuta H et al. (1997) Hepatic function in a family with a nonsense mutation (R154X) in the hepatocyte nuclear factor-4 $\alpha /$ MODY1 gene. J Clin Invest100:1400-1405

20. Bulman MP, Dronsfield MJ, Frayling T et al. (1997) A missense mutation in the hepatocyte nuclear factor $4 \alpha$ gene in a UK pedigree with maturity-onset diabetes of the young. Diabetologia 40:859-862

21. Hani EH, Suaud L, Boutin P et al. (1998) A missense mutation in hepatocyte nuclear factor- $4 \alpha$, resulting in a reduced transactivation activity, in human late-onset non-insulin-dependent diabetes mellitus.J Clin Invest 101:521-526

22. Lehto M, Wipemo C, Ivarsson SA et al. (1999) High frequency of mutations in MODY and mitochondrial genes in Scandinavian patients with familial early-onset diabetes. Diabetologia 42:1131-1137

23. Moller AM, Dalgaard LT, Ambye L et al. (1999) A novel Phe75fsdelT mutation in the hepatocyte nuclear factor- $4 \alpha$ gene in a Danish pedigree with maturity-onset diabetes of the young. J Clin Endocrinol Metab 84:367-369

24. Malecki MT, Yang Y, Antonellis A, Curtis S, Warram JH, Krolewski AS (1999) Identification of new mutations in the hepatocyte nuclear factor $4 \alpha$ gene among families with early onset Type 2 diabetes mellitus. Diabet Med 16:193-200

25. Bulman MP, Ellard S, Hattersley AT (2000) R127W in $\mathrm{HNF} 4 \alpha$ is a loss-of-function mutation causing maturityonset diabetes of the young (MODY) in a UK Caucasian family. Diabetologia 43:1203

26. Barrio R, Bellanne-Chantelot C, Moreno JC et al. (2002) Nine novel mutations in maturity-onset diabetes of the young (MODY) candidate genes in 22 Spanish families. J Clin Endocrinol Metab 87:2532-2539

27. Matthews DR, Hosker JP, Rudenski AS, Naylor BA, Treacher DF, Turner RC (1985) Homeostasis model assessment: insulin resistance and beta-cell function from fasting plasma glucose and insulin concentrations in man. Diabetologia 28:412-419

28. Byrne MM, Sturis J, Fajans SS et al. (1995) Altered insulin secretory responses to glucose in subjects with a mutation in the MODY1 gene on chromosome 20. Diabetes 44:699-704

29. Lausen J, Thomas H, Lemm I et al. (2000) Naturally occurring mutations in the human $\mathrm{HNF} 4 \alpha$ gene impair the function of the transcription factor to a varying degree. Nucleic Acids Res 28:430-437

30. Yamagata K, Oda N, Kaisaki PJ et al. (1996) Mutations in the hepatocyte nuclear factor- $1 \alpha$ gene in maturity-onset diabetes of the young (MODY3). Nature 384: 455-458

31. Zha J, Harada H, Yang E, Jockel J, Korsmeyer SJ (1996) Serine phosphorylation of death agonist BAD in response to survival factor results in binding to 14-3-3 not BCLX(L). Cell 87:619-628

32. Hayhurst GP, Lee YH, Lambert G, Ward JM, Gonzalez FJ (2001) Hepatocyte nuclear factor $4 \alpha$ (nuclear receptor 2A1) is essential for maintenance of hepatic gene expression and lipid homeostasis. Mol Cell Biol 21:1393-1403

33. Kim JK, Fillmore JJ, Chen Y et al. (2001) Tissue-specific overexpression of lipoprotein lipase causes tissue-specific insulin resistance. Proc Natl Acad Sci USA 98:7522-7527

34. Lehto M, Bitzen PO, Isomaa B et al. (1999) Mutation in the HNF- $4 \alpha$ gene affects insulin secretion and triglyceride metabolism. Diabetes 48:423-425 
35. Shih DQ, Dansky HM, Fleisher M et al. (2000) Genotype/phenotype relationships in HNF-4a/MODY1: haploinsufficiency is associated with reduced apolipoprotein (AII), apolipoprotein (CIII), lipoprotein(a), and triglyceride levels. Diabetes 49:832-837

36. Iwasaki N, Oda N, Ogata M et al. (1997) Mutations in the hepatocyte nuclear factor-1 $\alpha / \mathrm{MODY} 3$ gene in Japanese subjects with early- and late-onset NIDDM. Diabetes 46:1504-1508
37. Urhammer SA, Rasmussen SK, Kaisaki PJ et al. (1997) Genetic variation in the hepatocyte nuclear factor- $1 \alpha$ gene in Danish Caucasians with late-onset NIDDM. Diabetologia 40:473-475

38. Yamada S, Nishigori H, Onda H (1997) Mutations in the hepatocyte nuclear factor- $1 \alpha$ gene (MODY3) are not a major cause of late-onset NIDDM in Japanese subjects. Diabetes $46: 1512-1513$ 